\title{
Length-weight relationship and condition factor of Indian major carps of Vallabhsagar Reservoir, Gujarat, India
}

\author{
NANDITA SONI AND N. C. UJJANIA \\ Department of Aquatic Biology, Veer Narmad South Gujarat University, Surat - 395 007, Gujarat, India \\ e-mail: nanditasoni17@yahoo.in
}

\begin{abstract}
The present study elucidated the length-weight relationship and condition factor of the Indian major carps catla Catla catla, rohu Labeo rohita and mrigala Cirrhinus mrigala from the Vallabhsagar Reservoir, Gujarat. The mean total lengths (TL) recorded for the three species during the study were, $40.734 \pm 0.614,39.285 \pm 0.892$ and $38.010 \pm 0.925 \mathrm{~cm}$ while mean weights (WT) recorded were $914.141 \pm 46.672,969.306 \pm 93.738$ and $635.714 \pm 51.129 \mathrm{~g}$ for catla, rohu and mrigal, respectively. The length and weight variables showed linear relationship as depicted by correlation coefficient (r) values of 0.987 in catla, 0.956 in rohu and 0.967 in mrigal. Growth in the three species was found to be positive allometric and exponent values (b) obtained were 3.104, 3.342 and 3.049 for catla, rohu and mrigal respectively. The condition factor $(\mathrm{K})$ and relative condition factor $(\mathrm{Kn})$ estimated revealed the well being of fish and conducive environment of the reservoir. Results of the study provided baseline information which would be helpful for the scientific management of Indian major carp fisheries in the Vallabhsagar Reservoir in Gujarat.
\end{abstract}

Keywords: Allometric growth, Condition factor, Indian major carps, Length-weight relationship

Vallabhsagar is popularly known as Ukai Reservoir is a multi-purpose dam in Tapi River $\left(73^{\circ} 32^{\prime} 25^{\prime \prime}\right.$ to $78^{\circ} 36^{\prime}$ $30^{\prime \prime} \mathrm{E}$ and $20^{\circ} 05^{\prime} 00^{\prime \prime}$ to $22^{\circ} 52^{\prime} 30^{\prime \prime} \mathrm{N}$ ) and is one of the largest water bodies of Gujarat State. This reservoir is rich in different species of fishes including Indian major carps (IMCs), minor carps and catfishes. The total fish production from the reservoir is $10316 \mathrm{t}$ wherein the contribution of Indian major carps is comparatively high $(29.11 \%)$ which amounts to $3003 \mathrm{t}$ during 2010-11 (Anon., 2011).

The study of length-weight relationship (LWR) has great importance in fishery biology as it helps to understand the growth, maturity, reproduction and general wellbeing of fish (LeCren, 1951). LWR can be useful for the assessment of biomass and for stock assessment models (Wootton, 1990; Moutopoulos and Stergious, 2002). It is also used to assess inter and intra specific differences on the basis of morphology of fish species from different habitats or regions (Moutopoulos and Stergious, 2002). All the fish species have their own growth rate depending upon their genetic makeup, food resources available and the environmental conditions. In this context, the cube law is considered as one of the important method to determine the growth of fish. For this length and weight parameters are used and it explains that the weight of a fish increases three times more of the length. Condition factor $(\mathrm{K})$ and relative condition factor $(\mathrm{Kn})$ are very important biological parameters which show the suitability and richness of waterbody for fish growth. Condition factor $(\mathrm{K})$ indicates the sexual maturity, food availability and its utilisation by fish. Further, this may be useful to assess even age and sex of some species (Anibeze, 2000). On the other hand, relative condition factor $(\mathrm{Kn})$ is used as an index for comparing the observed weight of an individual with the mean weight for that length (Mir et al., 2012) and it is a preferred index to compare the condition of fish among populations as well as species. Significant changes in body shape of fish from different populations or species can be easily evaluated by condition factor and relative condition factor (Froese, 2006).

In Indian subcontinent, the study on LWR and condition factors of Indian major carps were attempted by Khan and Hussain (1941) from the Departmental Fish Farm, Chhenawan, Punjab and recently this aspect was explained by number of researchers. Naeem et al. (2010) reported the LWR and condition factor of hybrid $C$. catla male and L. rohita female from Multan, Pakistan. Prasad et al. (2012) studied the LWR and condition factor of L. rohita from Govindgarh Lake, Rewa. Growth pattern of Labeo calbasu in terms of LWR studies was reported by Rizvie et al. (2012). LWR and condition factor of IMCs from Rajasthan was reported by Ujjania (2012) and Ujjania et al. (2012). The LWR of IMCs and Chinese carps in Raipur Reservoir of Gwalior, Madhya Pradesh was studied by Saxena and Saxsena (2013). The present study investigated the length-weight relationship, condition factor, relative condition factor and growth of Indian major carps in Vallabhsagar Reservoir in Gujarat. 
Fish samples were collected from the commercial landing centres situated on the bank of Vallabhsagar Reservoir (Fig. 1.) during March to August 2013. Length-weight relationships of 283 fish samples were analysed from log transformed data on length and weight collected every month. The total length (TL) was measured from tip of snout to the posterior end of caudal fin (corrected up to $0.5 \mathrm{~cm}$ ) with the help of measuring tape, while body weight (WT) was taken with the help of a digital balance (corrected up to $1.0 \mathrm{~g}$ ) after removing water and mucus from the body of fish.

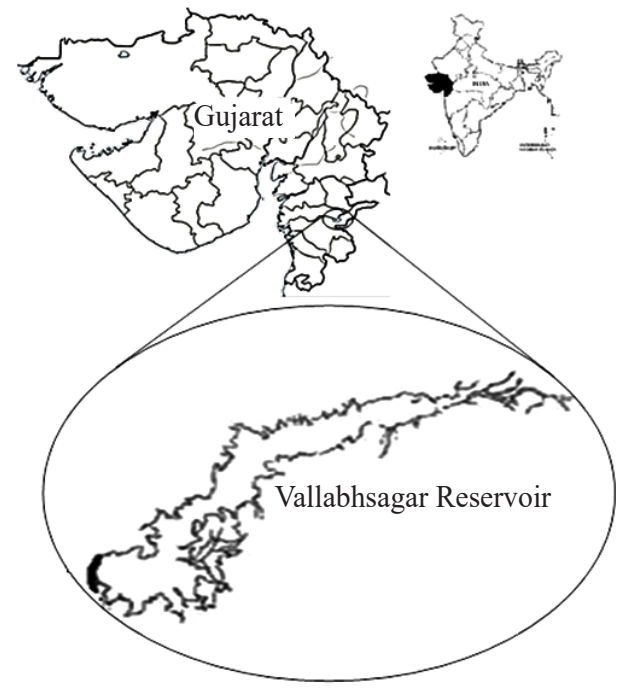

Fig. 1. Location of the study area

The length weight key of Biswas (1993) and parabolic equation of Froese (2006) were used for the statistical relationship between length and weight:

$$
\begin{aligned}
& \mathrm{W}=a \mathrm{~L}^{\mathrm{b}} \\
& \log \mathrm{W}=\log \mathrm{a}+\mathrm{b} \log \mathrm{L} \\
& \text { where: } \mathrm{W}=\text { weight of fish }(\mathrm{g}), \mathrm{L}=\text { length of fish (c), } \\
& \mathrm{a}=\text { Coefficient, } \mathrm{b}=\text { Exponent }
\end{aligned}
$$

The coefficient of correlation (r) was calculated following the standard statistical procedure of Snedecor and Cochran (1967). In addition, the condition factor (K) was calculated by the following equation of Fulton (1904):

$$
\mathrm{K}=(\mathrm{W} \times 100) / \mathrm{L}^{3}
$$

where, $\mathrm{W}=$ Weight of fish $(\mathrm{g}), \mathrm{L}=$ Total length of fish $(\mathrm{cm})$

The relative condition factor $(\mathrm{Kn})$ accounts for changes in form or condition with increase in length and it was calculated using equation given by LeCren (1951).

$$
\mathrm{Kn}=\mathrm{W} / \mathrm{w}
$$
of fish $(g)$
For statistical analysis for estimation of regression and correlation coefficients, computer package PAST was used.

The LWR of IMCs viz., catla (C. catla), rohu (L. rohita) and mrigal (C. mrigala) of Vallabhsagar Reservoir was determined from logarithmic transformed data of TL and WT. During this study, the observed mean length of catla was $40.73 \pm 0.614 \mathrm{~cm}$, for rohu $39.28 \pm 0.892 \mathrm{~cm}$ and for mrigal it was $38.01 \pm 0.925 \mathrm{~cm}$, while mean weight of $914.14 \pm 46.672$, $969.30 \pm 93.73$ and $635.714 \pm 51.129 \mathrm{~g}$ were recorded for catla, rohu and mrigal, respectively (Table 1). The length and weight variables are highly correlated as evident from the linear correlation (Fig. 2a-c). Correlation coefficient (r) values of $0.987,0.955$ and 0.967 were found for catla, rohu and mrigal, respectively (Table 1). The results of the present investigation for the LWR of these three species are in agreement to the findings of Naeem et al. (2010) on hybrid catla and rohu from Multan, Pakistan as well as with the findings of Ujjania (2012) and Ujjania et al. (2012) on Indian major carps from selected water bodies of Southern Rajasthan. Mir et al. (2014) and Parmar and Bhatia (2014) also reported similar findings on rohu and mrigal in six drainages of Ganga River system and Pong Reservoir in Himachal Pradesh, India. The exponent values 'b' for catla (3.104), rohu (3.342) and mrigal (3.048) were observed to be $>3$, which indicate that the growth in all the three species is positively allometric. This means that the weight of fish is more as compared to the cube of length. Similar findings for exponent (b) were reported by Ujjania et al. (2012) from Mahi Bajaj Sagar, Rajasthan; Naeem et al. (2010) on hybrid catla and rohu from Multan Pakistan; Mir et al. (2014) on rohu in Ganga Basin; Parmar and Bhatia (2014) on mrigal in Pong Reservoir, Himachal Pradesh and Brraich and Kaur (2015) on catla in Harike wetland, Punjab.

Condition factor $(\mathrm{K})$ and relative condition factor $\mathrm{Kn})$ are important factors which accurately describe the well being of fish in aquatic environment. In this study, the average values of ' $\mathrm{K}$ ' for catla $(1.349 \pm 0.015)$, rohu $(1.230 \pm 0.022)$ and mrigal $(1.00 \pm 0.012)$ were observed to vary (Table 1). The condition factor (K) and exponent (b) are directly proportional. When the exponent $b=3$, the value of ' $\mathrm{K}$ ' will remain constant at 1 . But when the value of exponent changes to either $b>3$ or $b<3$, the value of condition factor will also either increase or decrease (Naeem et al., 2000; Naeem and Salam, 2004). The observations of Mir et al. (2012) are based on the inference that heavier fish at a particular length are in good condition. The values of relative condition factor ' $K n$ ' were $1.005 \pm 0.011,1.0145 \pm 0.018$ and $1.016 \pm 0.012$ for catla, rohu and mrigal, respectively (Table1).

The results of condition factor and relative condition factor observed in the present study indicate that the growth rate of Indian major carps in Vallabhsagar Reservoir is satisfactory. Saxena et al. (2013) observed the condition factor for catla to be 1.04-1.99, 1.03-1.46 for rohu and 
Table 1. Statistical parameters of length-weight relationships of Indian major carps from Vallabhsagar Reservoir

\begin{tabular}{llll}
\hline Parameter & Catla catla & Labeo rohita & Cirrhinus mrigala \\
\hline $\mathrm{a}$ & -2.372 & -2.466 & -2.083 \\
$\mathrm{~b}$ & 3.104 & 3.342 & 3.049 \\
$\mathrm{r}$ & 0.987 & 0.956 & 0.967 \\
$\mathrm{~K}$ & $1.349 \pm 0.015$ & $1.230 \pm 0.023$ & $1.0001 \pm 0.012$ \\
Kn & $1.005 \pm 0.011$ & $1.014 \pm 0.018$ & $1.0167 \pm 0.013$ \\
TL min. $(\mathrm{cm})$ & 29.0 & 30.0 & 34.0 \\
TL max. $(\mathrm{cm})$ & 82.0 & 58.0 & 65.0 \\
TL mean $(\mathrm{cm})$ & $39.285 \pm 0.893$ & $40.743 \pm 0.614$ & $43.639 \pm 0.0 .793$ \\
WT min. $(\mathrm{g})$ & 323 & 233 & 352 \\
WT max. $(\mathrm{g})$ & 8000 & 2434 & 2527 \\
WT mean $(\mathrm{g})$ & $969.306 \pm 93.739$ & $914.142 \pm 46.673$ & $896.806 \pm 58.699$ \\
$\mathrm{n}$ & 98 & 113 & 72 \\
\hline
\end{tabular}

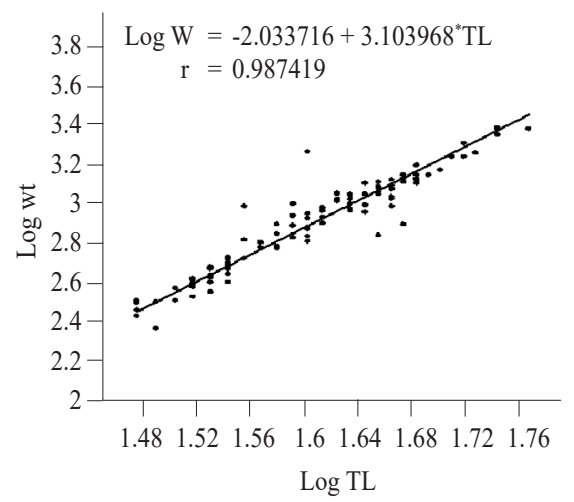

(a)

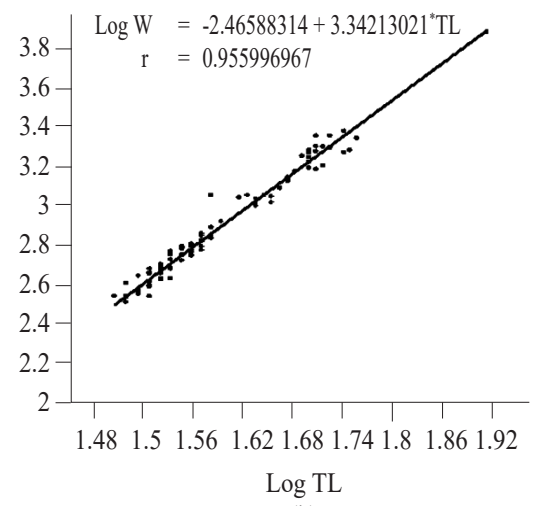

(b)

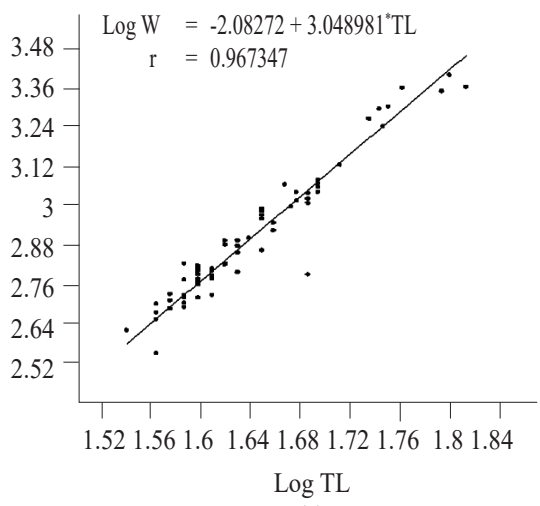

(c)

Fig. 2. Length-weight relatioships of Indian major carps from Vallabhsagar. a: Catla, b: Rohu and c: Mrigal

0.9-1.4 for mrigal from Raipur Reservoir, Gwalior, which is very close to the present study. Similar results were also revealed by Pandey et al. (1998) for L. rohita (0.917-1.04), C. catla (0.903-1.07) and C. mrigala (0.976-1.031) from a sodic soil pond in Uttar Pradesh and by Narejo (2006) for Cirrhinus reba (1.01) in Manchar lake, Pakistan. Mir et al. (2012) reported the condition factor of male rohu to vary between 1.20 to 1.51 while it was 1.26 to 1.40 in case of female rohu from six different rivers of Ganga basin.

\section{References}

Anibeze, C. I. P. 2000. Length-weight relationship and relative condition factor of Heterobranchus longifilis (Valencienness) from Idodo River, Nigeria. NAGA, the ICLARM Quarterly, 23: $34-35$.

Anon. 2011. Gujarat agriculture statistics at a glance 2010-11. Directorate of Economics and Statistics, Government of Gujarat.

Brraich, O. S. and Kaur, L. 2015. Length-weight relationship of Catla catla (Hamilton-Buchanan), from Harike wetland (Ramsar site), Punjab, India. Int. Res. J. Biol. Sci., 4(6): 44-47.
Biswas, S. P. 1993. Length-weight relationship and condition factor. In: Manual of methods of fish biology, New Delhi, South Asian Publisher, p.60-64.

Froese, R. 2006. Cube law, condition factor and weight-length relationships. J. Appl. Ichthol., 22: 241-253.

Fulton, T. W. 1904. The rate of growth of fishes. $22^{\text {nd }}$ Annual Report of the Fishery Board of Scotland, (3): 41-241.

Khan, R. A. and Hussain, A. 1941. The length weight relationship of Labeo rohita and Cirrhinus mrigala. Proc. Indian Acad. Sci., 20: 120-123.

LeCren, E. D. 1951. The length-weight relationship and seasonal cycle in gonad weight and condition in the perch (Perca fluviatilis). J. Anim. Ecol., 20: 219-223.

Mir, J. I, Shabir, R. and Mir, F. A. 2012. Length-weight relationship and condition factor of Schizopyge curvifrons (Heckel, 1838) from River Jhelum Kashmir, India. World J. Fish. Mar. Sci., 4(3): 325-329.

Mir, J. I., Sarkar, U. K., Gusain, O. P. and Dwivedi, A. K. 2014. Length-weight relationship of the Indian major carp, Labeo rohita (Cypriniformes; Cyprinidae) from six drainages of Ganga basin, India. Cuadernos de Investigacion UNED, 7(1): 71-77. 
Moutopoulos, D. K. and Stergious, K. I. 2002. Length-weight and length-length relationships of fish and species from Aegean Sea (Greece). J. Appl. Ichthiol., 18: 200-203.

Naeem, M. and Salam, A. 2004. Morphometric studies on Oreochromis nilotica (male) in relation to body size from Islamabad, Pakistan. Punjab Univ. J. Zool., 19: 73-81.

Naeem, M., Salam, A. and Bhatti, M. N. 2000. Morphometric studies of cold water fish rainbow trout Oncorhynchus mykiss in relation to body size. Pak. J. Zool., 1: 55-62.

Naeem, M., Salam, A., Ishtiaq, A. and Shafique, S. 2010. Lengthweight and condition factor relationship of farmed hybrid (Catla catla x Labeo rohita) from Multan, Pakistan. Shindh Uni. Res. J. Sci. Ser., 42(2): 35-38.

Narejo, N. T. 2006. Length-weight relationship and relative condition factor of carp Cirrhinus reba from Manchar Lake, Distt. Dadu, Sindh, Pakistan. Pak. J. Zool., 38(1): 11-14.

Pandey, A. C. and Sharma, M. K. 1998. Bionomics of the Indian major carps cultivated on sodic soil pond conditions in U. P. India. Indian J. Fish., 45: 207-210.

Parmar, A. and Bhatia, N. P. 2014. Age, growth and length weight relationship of Cirrhinus mrigala from Pong Reservoir,
Himanchal Pradesh, India. Int. J. Fauna Biol. Studies, 1(3): 11-17.

Prasad, U. Satan and Prasad, P. D. and Amitabh, P. 2012. Lengthweight relationship and condition factor of Labeo rohita in Govindgarh Lake, Rewa (M.P.). Indian J. Res., 1(12):185-187.

Rizvi, A. F., Amitabh, C. D. and Singh, K. P. 2012. Growth pattern of Labeo calbasu affected by socio-geographical condition of the riverine habitat. Curr. Res. J. Biol. Sci., 4(3): 250-257.

Saxena, M. and Saksena, D. N. 2013. Growth of Indian major carps and a Chinese carps in extensive culture system in Raipur Reservoir, Gwalior, M. P., India. J. Fish. Aquac., 4(1): 75-81.

Snedecor, S. W. and Cochran, W. G. 1967. Statistical methods. Oxford and IBH Publishing Co., New Delhi, 435 pp.

Ujjania, N. C. 2012. Comparative age and growth of Indian majors carp (Catla catla) in selected water bodies of Southern Rajasthan. Res. J. Rec. Sci., 1: 17-22.

Ujjania, N. C., Kohli, M. P. S. and Sharma, L. L. 2012. Lengthweight relationship and condition factor of Indian major carp (C. catla, L. rohita, C. Mrigala) in Mahi Bajaj Sagar, India. Res. J. Biol., 2(1): 30-36.

Wooton, J. R. 1990. Ecology of teleost fishes, Chapman and Hall, London, England. 